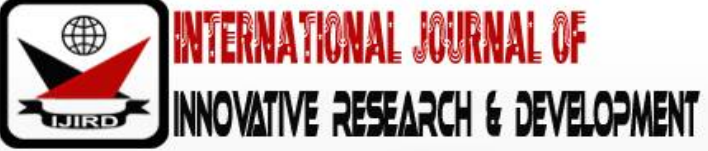

ISSN 2278 - 0211 (Online)

\section{Effectiveness of Colouring and Playdlough Method on Fine Motoric Skills of Pre School Student in Mojokerto, Indonesia}

\author{
Ika Suhartanti \\ Lecture, nursing department of STIKes Majapahit, Mojokerto, Indonesia \\ Zulfa Rufaida \\ Lecture, midwifery department of STIKes Majapahit, Mojokerto, Indonesia \\ Widy Setyowati \\ Lecture, nursing department of STIKes Majapahit, Mojokerto, Indonesia \\ Fitria Wahyu Ariyanti \\ Lecture, nursing department of STIKes Majapahit, Mojokerto, Indonesia
}

\begin{abstract}
:
Fine motor development is still a problem of the children and toddlers development in the world and Indonesia. One of the efforts to improve fine motor skills is by coloring and playdought methods for preschoolers as an educational game therapy. This study aimed to examine the fine motor development of preschoolers through coloring and playdough methods. This research design used a series of pretest-posttest design by involving 60 kindergarten students which were divided into 4 groups consisting of 15 respondents. First group was given the playdought method, $2^{\text {nd }}$ group was given the coloring intervention, $3^{\text {rd }}$ group was given the coloring method and playdough and $4^{\text {th }}$ group was the control. Interventions were given 2 times a week for 4 weeks. Before the intervention was given, the whole group was pre-tested. Evaluation of fine motor skills was done by observation that use performance test conducted at the end of each experiment. The results of data collection were then analyzed using multivariate anova. The results of the study showed that after the post test at $4^{\text {th }}$ week, there was a change in fine motor skills ranging from groups 1 to $4(\mathrm{~F}=328,961$ and $\mathrm{p}$ value $=0,000$ ). The fine motor skills of children who received the best combination of coloring and playdough therapy (mean $=85.33$, SD $=1.29$ ) increased almost 4 times more than the initial measurement $($ mean $=$ 18.33, $\mathrm{SD}=4.74$ ) compared to the three other groups.
\end{abstract}

Keywords: Colouring, playdough, fine motoric, pre school

\section{Introduction}

Preschool is a very important period in children's development because of the interaction of a child in a period of growth and development, especially motor functions, language, cognitive, play and emotions (Ratnasari, 2017). One area of basic development that is important for children is physical motor development. The impact of delays in fine motor development is that children have low self-confidence, are less active and have difficulty adapting to the environment which ultimately degrades the quality of the nation's next generation due to low human resources (Dhita Kris Prasetyanti, 2017).

Dudley's study noted 3.3\% -17\% of children experience growth retardation (Dudley, 2010). The Indonesian Pediatrician Association Survey (IDAI) in East Java explains that children with normal development according to age are $53 \%$, doubtful development (requires deeper examination) by $13 \%$, and developmental deviations by $34 \%$. Of the developmental deviations, $10 \%$ are affected by gross motor deviations (such as walking, sitting), 30\% of fine motor deviations (such as writing, holding), $44 \%$ speak of language deviations and $16 \%$ of the socialization of independence (Yurika Dewi, 2009). The results of Jubaidah research (2018) at TK Dharma Wanita 01 Kalibendo Lumajang Jawa Timur Province, explained that of the 40 kindergarten students who had not yet been given an experiment, all of them had less development. All of the above reports explain that the motor development of preschool children is a major problem that needs attention.

The development of fine motor skills for children is done through hands-on using various creative tools and media such as brushes, pencils, scissors, clay, plasticine and others. By using these creative media, children can carry out activities that can train the muscles of the hand, eye and mind coordination (Dewi Rohana, 2017). Children who are given therapy to play coloring pictures of children will more easily express their thoughts, because paintings and drawings are extraordinary media for expression. Children more easily express their thoughts and feelings through art, because humans 
think first in the imagination and then learn to be translated into words (Kusdyawati, 2009). Playing plasticine is expected that children can make something new that provides artistic value according to their ideas and creativity. This activity has the main goal to broaden the child's attention span, make the child understand and carry out instructions, support the development of small muscles and improve eye-hand coordination The play of plasticine wax is useful for showing the expression and emotions of children (Dhita Kris Prasetyanti, 2017). The general objective of this research was to determine the effect of playdough and coloring games on the development of fine motor development in pre-school age children. Researchers aimed to examine the effect of providing playdough games on the development of fine motor skills in pre-school age children, assessing the effect of providing coloring games on the motor skills of pre-school children and comparing the duration of the two treatments in increasing fine motor skills and the effectiveness of the two treatments when combined .

\subsection{Conceptual Frame work}

Fine motor development is an overall process of changing the ability of children to move by using small muscles used for activities such as drawing, colouring and squeezing and requires high precision. According to (Dhita Kris Prasetyanti, 2017) the causes of delays in fine motor development are: Children have low self-confidence, Children are less active, and Children have difficulty adapting to the environment. Colouring an image is an activity of giving colour to an image or imitation of an item made with pencil / colouring streaks on paper. One game that is suitable for pre-school children is colouring pictures, where children begin to like and recognize colours and recognize the shapes of objects around them. Colouring is one of the games that gives children the opportunity to be free of expression and very therapeutic (Paat, 2010).

Some of the benefits of colouring activities carried out by children are developing motor skills, understanding lessons, self-expression, learning concentration and skilled in making decisions. Playdough is soft wax that is easy to shape as desired with various colours due to its soft texture (Alini, 2017). Playdough therapy is an attempt to change problem behaviour, by placing children in a design situation by using soft wax that is easily formed according to the wishes and imagination of the maker. Many factors affect the development of fine motor skills in children. This is explained in the following framework:

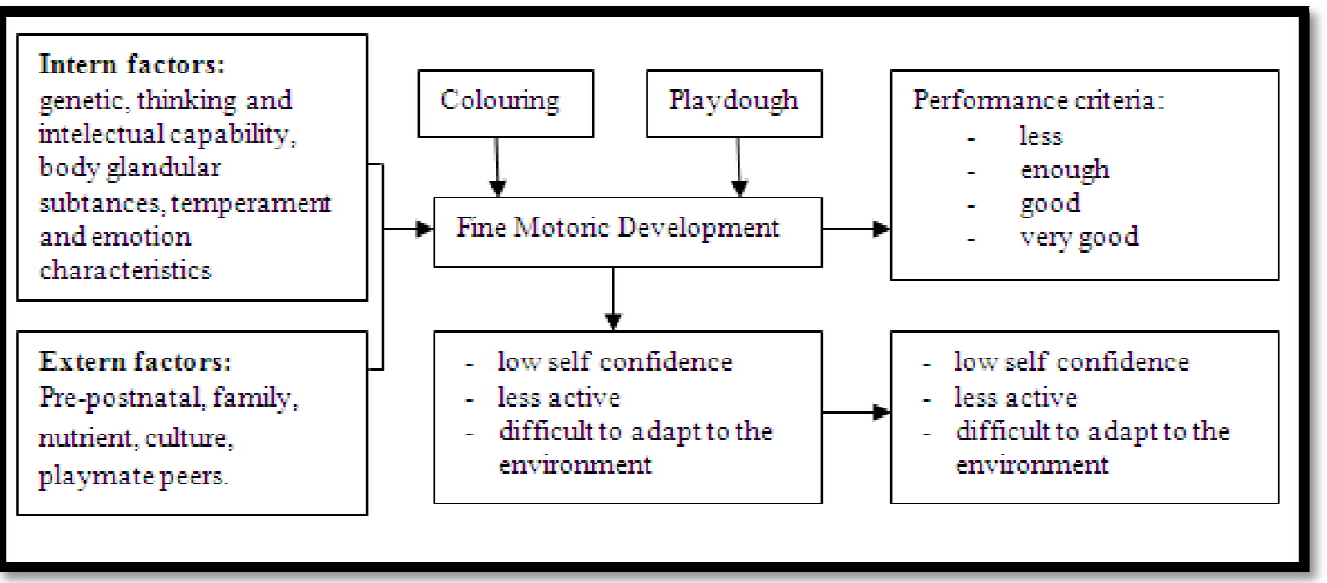

Figure 1

\section{Materials and Methods}

\subsection{Research Design}

The research design is a strategy research in identifying problems before the final planning of data collection and research design is used to define the structure of the research to be carried out. The design is used as a guide for planning the implementation of a study (Nursalam, 2016). The design of this study used a quasi-experimental design with a serial pre - post test design to express the causal relationship by involving several groups of subjects. The subject group was observed before the intervention was carried out and then observed again after the intervention. Basically, this design is a time series design, using a comparison group (control). The purpose of this design is to compare the results of interventions before and after the intervention in the case group, with the control group that was not given the intervention. In this design, the grouping of samples in the experimental group and the control group is not done randomly (Riyanto, 2011).

\subsection{Population and Sample}

The population of this research was kindergarten students in Mojokerto. Samples were selected from 4 Kindergartens randomly with a total of 170 students, which were then divided into 4 groups. Determination of sample size using the following formula:

$\mathrm{n}_{1}=\mathrm{n}_{2}=\mathrm{n}_{3}=\mathrm{n}_{4}=\left(\frac{(\mathrm{Z} \alpha+Z \beta) S}{\mathrm{X}_{1}-\mathrm{X}_{2}}\right)^{2}$ 
Note :

$\mathrm{Z}_{\alpha} \quad=$ alfa standard deviation $(1,64)$

$\mathrm{Z}_{\beta} \quad=$ beta standard deviation $(1,28)$

$\mathrm{S} \quad=$ the standard deviation from the values difference between groups (based on Lestari research, 2018) is 36,04

$\mathrm{X}_{1}-\mathrm{X}_{2}=$ average minimum difference that is considered meaningful $(4,5)$

$\mathrm{n} \quad$ =sample size

$\mathrm{n}_{1}=\mathrm{n}_{2}=\mathrm{n}_{3}=\mathrm{n}_{4}=\frac{(1,64+1,28)^{2} 36,04}{(4,5)^{2}}$

$\mathrm{n}_{1}=\mathrm{n}_{2}=\mathrm{n}_{3}=\mathrm{n}_{4}=\frac{307,29}{20,25}$

$\mathrm{n}_{1}=\mathrm{n}_{2}=\mathrm{n}_{3}=\mathrm{n}_{4}=15,17=15$

Each group consisted of 15 respondents. So that the total respondents were 60 people. Sampling was determined purposively by considering the inclusion criteria as follows:

- Child was not sick

- The child lives with his biological parents

- The child does not experience abnormalities in the senses of the body and others.

\subsection{Experimental Procedure}

First group got playdough therapy, Second group got picture colouring therapy while Third group got playdough and colouring pictures combination and fourth group did not get therapy (as a control group). Each therapy (coloring and playdough) was given for 30 minutes 2 times in 1 week. The experiment lasted for 4 weeks. Before being given therapy, all groups got a pre test to see the initial condition of fine motor skills possessed by respondents. Then at the end of each treatment have a post test that carried out until the $4^{\text {th }}$ week.

\subsection{Data Collection and Analysis Techniques}

Data collection in this study used tests in the form of tests of student actions or performance (Sisiliani, 2015).

\begin{tabular}{|c|c|c|c|}
\hline Variable & Aspect & $\begin{array}{c}\text { Fine Motoric Capability } \\
\text { Indicators }\end{array}$ & Total Item \\
\hline $\begin{array}{c}\text { Fine Motor } \\
\text { Ability } \\
\text { Indicators }\end{array}$ & Writing & $\begin{array}{c}\text { 1. Student was able to } \\
\text { connect points }\end{array}$ & 4 \\
\cline { 2 - 4 } & Cutting & $\begin{array}{c}\text { 1. Students was able to } \\
\text { edit lines } \\
\text { 2. Students was able to } \\
\text { cut the picture }\end{array}$ & 2 \\
\cline { 2 - 4 } & Colouring & $\begin{array}{c}\text { 1. Students was able to } \\
\text { color images neatly } \\
\text { without out of line }\end{array}$ & 2 \\
\hline
\end{tabular}

Table 1 :Grating of Fine Motor Ability Test of Children

The assessment of the value scale by the following criteria:

- Score 1: students have not/ are not able to do the problems

- Score 2: students are able to connect dots, cut lines and drawings and colour drawings with the help of the teacher and the results are good / not good

- Score 3: students are able to connect the dots, cut out lines and images and colour the pictures independently and the results are not good

- Score 4: students are able to connect the dots, cut out lines and images and colouring images independently and the results are good

To find out the completeness of students using the formula (Sisiliani, 2015):

$\mathrm{PV}=\frac{R}{S M} X 100$

Information:

$\mathrm{PV}=$ Performance Value

$\mathrm{R}=$ the result of score obtained by students

$\mathrm{SM}=$ maximum score of all test items

The criterion score for achieving motor ability in the study is success with a minimum achievement of $65 \%$. The percentage of scores obtained by each student categorized into the following categories: 
b) $42.5 \%$ - $60 \%$ : enough

c) $62.5 \%-80 \%$ : good

d) $82.5 \%$ - 100\%: very good

The results of observations made 8 times were then analysed by using Multivariate Anova analysis to see the effectiveness of each treatment for each group.

\section{Results and Discussion}

3.1. Respondents Characteristic

\begin{tabular}{|c|c|c|c|}
\hline No & Respondents Characteristic & Frequency & $\mathbf{\%}$ \\
\hline $\mathbf{1}$ & Sex & 20 & 33,3 \\
& Man & 40 & 66,7 \\
\hline $\mathbf{2}$ & Woman & 15 & 25 \\
& Age & 30 & 50 \\
& 4 years old & 15 & 25 \\
\hline & 5 years old & 60 & 100 \\
\hline
\end{tabular}

Table 2 Respondents Characteristic at Kindergarden

The research respondent group was dominated by women and pre-school children aged 5 years. Pre-school age children are children before the age of 7 years who are given stimulus by preschool institutions to prepare themselves to enter the school world both socially, intellectually and emotionally so that it can have a good effect on the child's adaptation to their environment. According to Desmita (2017), before the age of 7 years, coordination between the eyes and hands (visiomotoric) owned by children is needed to aim, kick, throw and catch experience development, so that fine motor skills at that age have been developed.

\subsection{Fine Motoric Ability in Control Group}

\begin{tabular}{|c|c|c|c|c|c|c|}
\hline No & $\begin{array}{c}\text { Fine Motoric } \\
\text { Ability }\end{array}$ & Pre-Test & $\begin{array}{c}\text { Post Test } \\
\text { After 1 } \\
\text { week }\end{array}$ & $\begin{array}{c}\text { Post Test } \\
\text { After 2 } \\
\text { weeks }\end{array}$ & $\begin{array}{c}\text { Post Test } \\
\text { After 3 } \\
\text { weeks }\end{array}$ & $\begin{array}{c}\text { Post Test } \\
\text { After 4 } \\
\text { weeks }\end{array}$ \\
\hline 1 & Average & 18,200 & 22,667 & 31,333 & 41,333 & 65,667 \\
\hline 2 & Standard & 4,761 & 4,952 & 3,519 & 2,289 & 1,759 \\
& Deviation & & & & & \\
\hline 3 & Standard Error & 1,224 & 1,279 & 0,909 & 0,591 & 0,454 \\
\hline 4 & Confident & $15,697-$ & $19,924-$ & $29,385-$ & $40,066-$ & $64,692-$ \\
& Interval 5\% & 20,970 & 25,409 & 33,282 & 42,601 & 66,641 \\
\hline
\end{tabular}

Table 3: Fine Motoric Ability Score in Control Group

Base on early observation in the control group, the average respondent still has less fine motor skills, but with learning carried out by the teacher for 1 month, it can be seen that there was an improvement in fine motor skills with an average increase of 1.38 times higher than before. The highest increase occurred in the last week where an increase in fine motor skills was 1.58 times greater than the previous week. Up to third week, the average student still has fine motor skills at a less level. At the end of week 4, the average respondent had fine motor skills at a good level. 


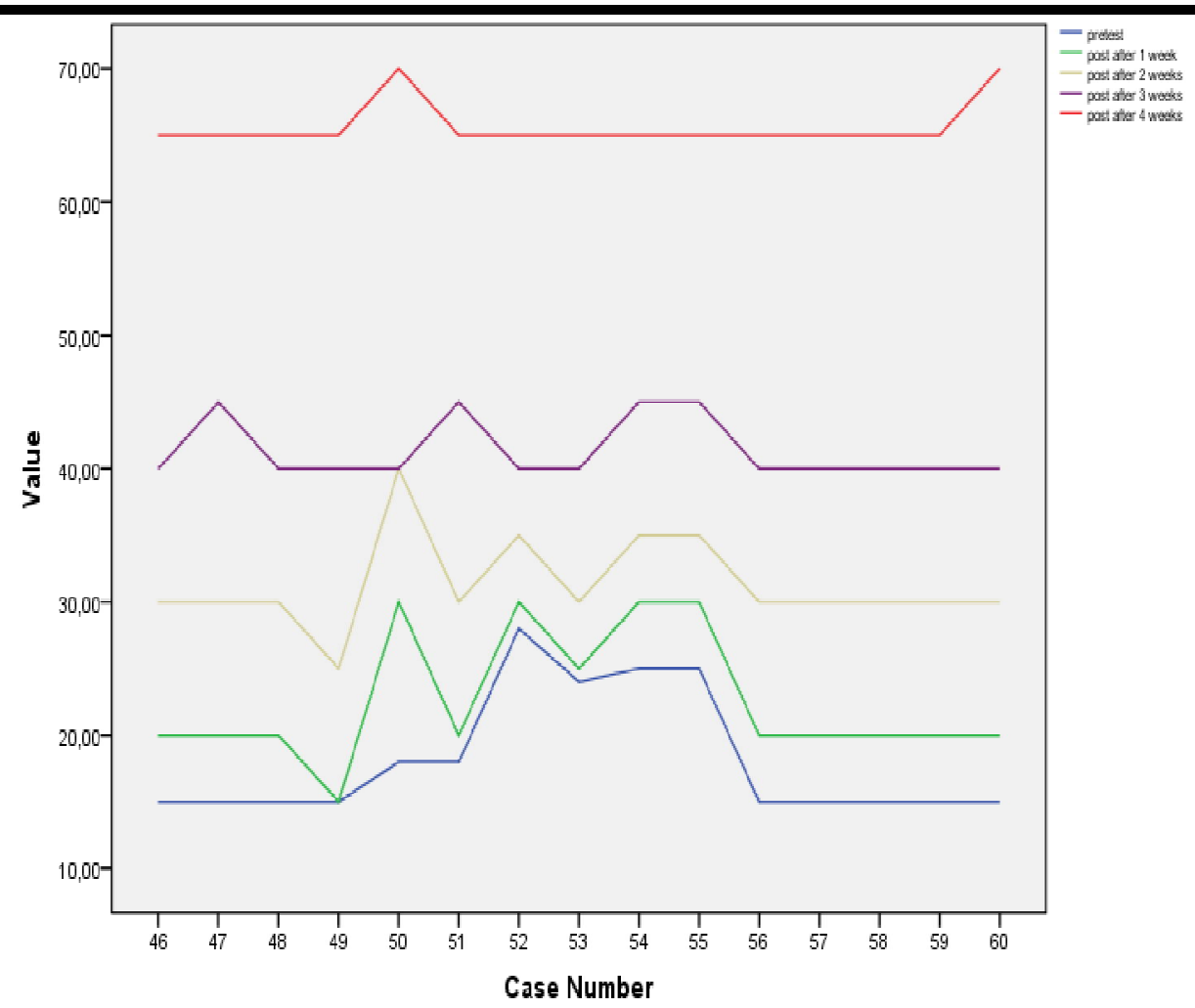

Figure 2: Line Diagram about the Fine Motoric Ability in Control Group

The figure above explains that an increase in the control group occurred only in the last week. Students begin to study well at the end of the first month in school. Fine motor is any activity that uses fine muscles in certain body parts, and requires complete coordination. Every child can achieve optimal fine motor development as long as he gets the right stimulation, more practice opportunities, and continuous guidance. Factors that influence a child's motor development are as follows: Factors of heredity (inheritance from birth), Environmental factors that influence organic and physical functions; Children's activities as free subjects with grace, ability, possessions, and have an effort to develop themselves (Nurhaeni, 2017). With the continuous stimulation provided by the school teacher and the ability to adjust students in the school led to an increase in the fine motor skills of the students even though the increase was not as high as the other groups.

3.3. Fine Motoric Ability in Colouring Group

\begin{tabular}{|c|c|c|c|c|c|c|}
\hline No & $\begin{array}{c}\text { Fine Motoric } \\
\text { Ability }\end{array}$ & Pre-Test & $\begin{array}{c}\text { Post Test } \\
\text { After 1 week }\end{array}$ & $\begin{array}{c}\text { Post Test } \\
\text { After 2 weeks }\end{array}$ & $\begin{array}{c}\text { Post Test } \\
\text { After 3 weeks }\end{array}$ & $\begin{array}{c}\text { Post Test } \\
\text { After 4 weeks }\end{array}$ \\
\hline 1 & Average & 18,200 & 36,333 & 39,800 & 54,00 & 83,000 \\
\hline 2 & Standard & 5,171 & 4,806 & 6,144 & 2,070 & 2,535 \\
& Deviation & & & & & \\
\hline 3 & Standard Error & 1,335 & 1,241 & 1,586 & 0,534 & 0,655 \\
\hline 4 & Confident & $15,336-$ & $33,672-$ & $36,398-43,202$ & $52,854-55,146$ & $81,596-84,404$ \\
& Interval 5\% & 21,064 & 38,995 & & & \\
\hline
\end{tabular}

Table 4: Fine Motoric Ability Score Colouring Group

There was a significant increase in fine motor skills at third week in coloring group and increased very high at $4^{\text {th }}$ week. Coloring in preschoolers aims to practice children skills, neatness and patience. 


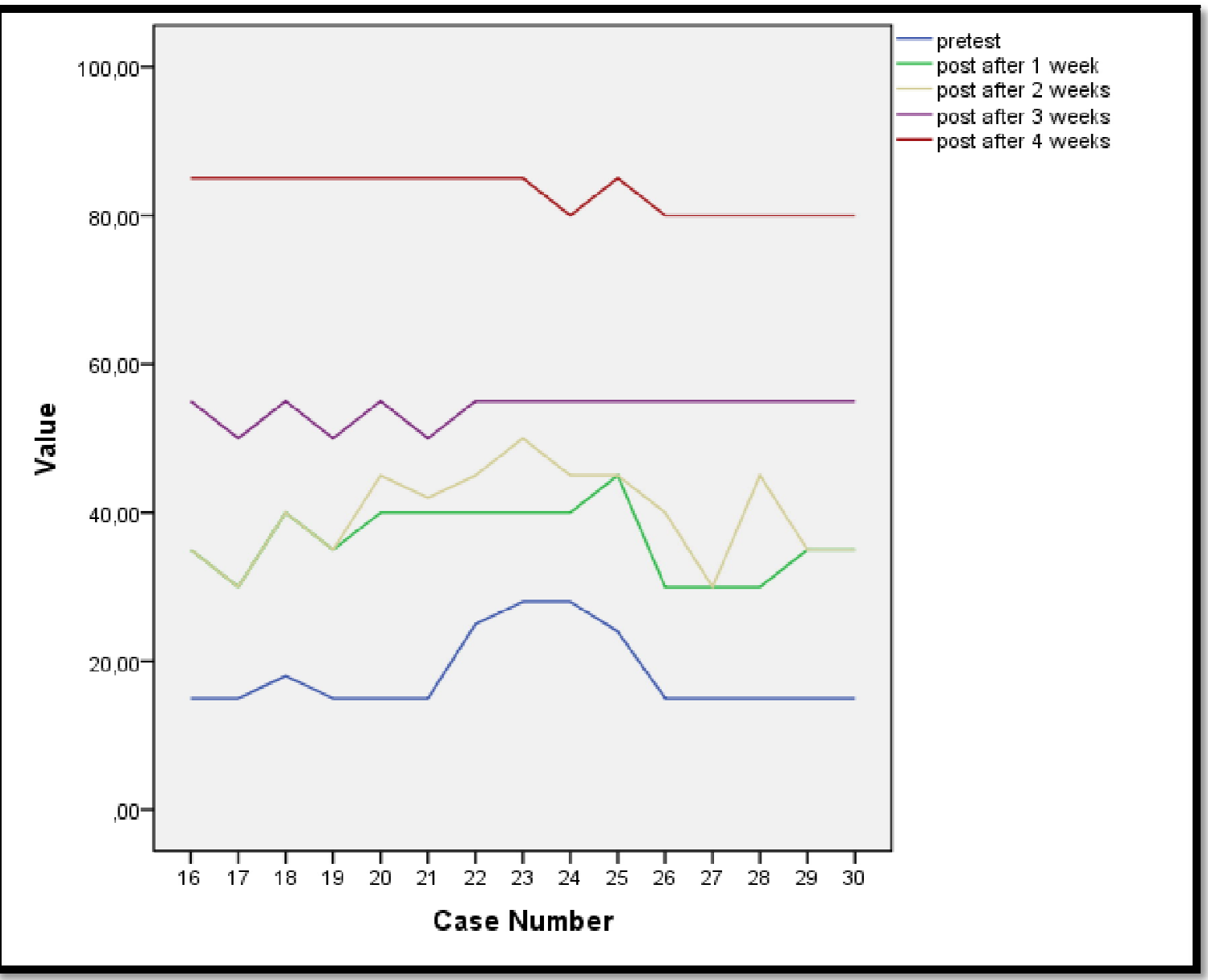

Figure 3: Line Diagram about the Fine Motoric Ability in Colouring Group

It is known that for second week, there has been an increase in fine motor skills of students almost to 2 times higher than before, and this continues to occur until last week. Most students have fine motor skills at good and very good levels. Skills are obtained from the child's ability to process the hands that are done repeatedly so that the child can control and direct as desired. Neatness seen from how the child gives color to the places that have been determined. The child will be more skilled to scratch the coloring media because it is used. Patience is obtained through the activity of choosing and determining the right composition according to his opinion, how many colors are used to determine the color composition (Sukardi, 2011). The effectiveness of the method of coloring pictures in improving the growth and development of children is able to provide opportunities for children to be free of expression and very therapeutic or as a healing game. In addition, the coloring method has the benefit of being a fun activity as well as training the motor nerves, creativity, and imagination of children. Different color and shape functions in play can provide a stimulus to the growth and development of children. By coloring pictures, children are better able to express their thoughts and feelings in the form of images. An outpouring of deep feelings can trigger students' fine motor skills for the better.

\subsection{Fine Motoric Ability in Playdough Group}

\begin{tabular}{|c|c|c|c|c|c|c|}
\hline No & $\begin{array}{c}\text { Fine Motoric } \\
\text { Ability }\end{array}$ & Pre-Test & $\begin{array}{c}\text { Post Test } \\
\text { After 1 week }\end{array}$ & $\begin{array}{c}\text { Post Test } \\
\text { After 2 weeks }\end{array}$ & $\begin{array}{c}\text { Post Test } \\
\text { After 3 weeks }\end{array}$ & $\begin{array}{c}\text { Post Test After 4 } \\
\text { weeks }\end{array}$ \\
\hline 1 & Average & 18,333 & 37,000 & 39,667 & 51,667 & 75,667 \\
\hline 2 & $\begin{array}{c}\text { Standard } \\
\text { Deviation }\end{array}$ & 4,761 & 6,761 & 5,815 & 2,439 & 1,759 \\
\hline 3 & Standard Error & 1,229 & 1,746 & 1,501 & 0,630 & 0,454 \\
\hline 4 & $\begin{array}{c}\text { Confident } \\
\text { Interval 5\% }\end{array}$ & $\begin{array}{c}15,697- \\
20,970\end{array}$ & $33,256-40,744$ & $36,447-42,887$ & $50,316-53,018$ & $74,692-76,641$ \\
\hline
\end{tabular}

Table 5: Fine Motoric Ability Score Playdough Group

Table 4 explained that the level of fine motor skills changed to be good at the end of the third week. The score of fine motor ability scores was 2.82 times higher than before getting the playdough stimulation method. Figure 3 explained that some respondent's fine motor skills have increase, from less to enough level at the second and third week. Children practice their fine motor skills using playdough which can be made by squeezing, forming an object according to their imagination (Dhita Kris Prasetyanti, 2017). The results of this study are similar with Sisiliani (2015) who explains that there is an increase in the fine motor skills of mentally retarded children in the middle-class category III through playing in the Damayanti Extraordinary School. Playdough media can help children to train the movement of the fingers and wrist 
muscles by pinching, squeezing and grasping. Fitrin's research (2016) explain that there is an effect of playdough media play therapy on fine motor skills in preschoolers at the Mawar kindergarten in Gowa Regency.

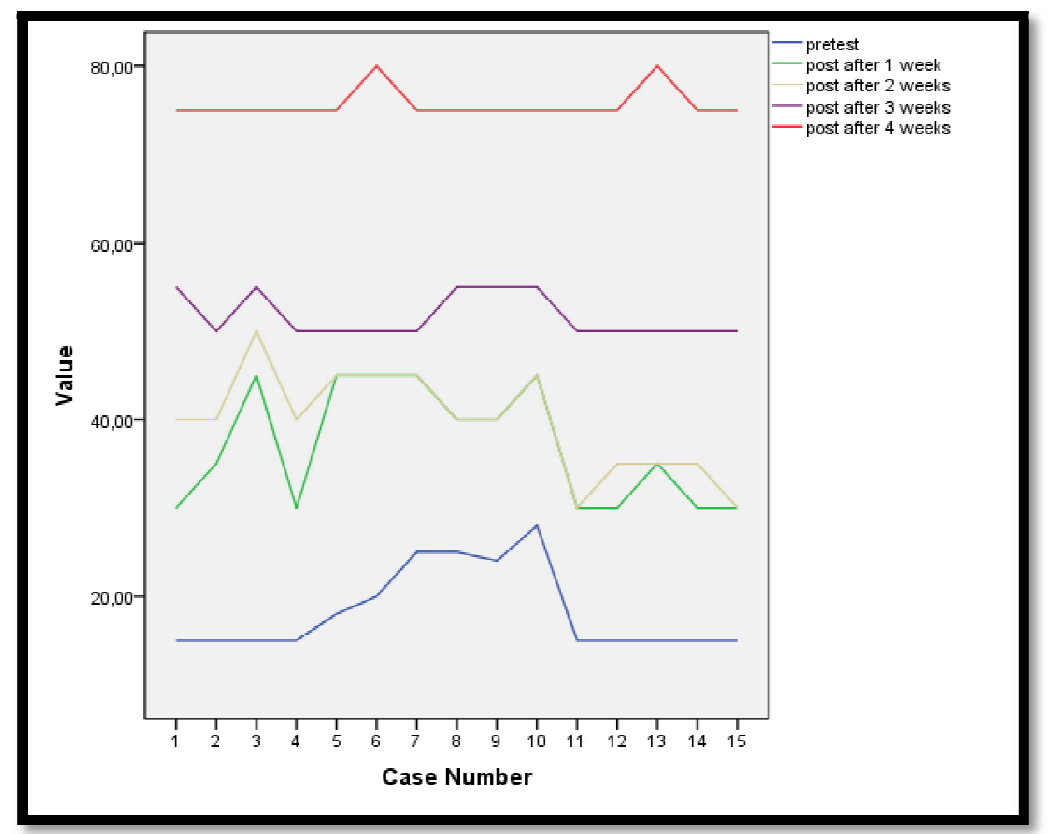

Figure 4: Line Diagram about the Fine Motoric Ability in Playdough Group

3.5. Fine Motoric Ability in Combination Group

\begin{tabular}{|c|c|c|c|c|c|c|}
\hline No & $\begin{array}{c}\text { Fine Motoric } \\
\text { Ability }\end{array}$ & Pre-Test & $\begin{array}{c}\text { Post Test } \\
\text { After 1 week }\end{array}$ & $\begin{array}{c}\text { Post Test After } \\
\text { 2 weeks }\end{array}$ & $\begin{array}{c}\text { Post Test } \\
\text { After 3 weeks }\end{array}$ & $\begin{array}{c}\text { Post Test } \\
\text { After 4 weeks }\end{array}$ \\
\hline 1 & Average & 18,333 & 46,667 & 49,200 & 64,667 & 85,333 \\
\hline 2 & $\begin{array}{c}\text { Standard } \\
\text { Deviation }\end{array}$ & 4,761 & 4,082 & 3,726 & 2,289 & 1,291 \\
\hline 3 & Standard Error & 1,229 & 1,054 & 0,962 & 0,591 & 0,333 \\
\hline 4 & $\begin{array}{c}\text { Confident } \\
\text { Interval 5\% }\end{array}$ & $\begin{array}{c}15,697- \\
20,970\end{array}$ & $44,406-48,928$ & $47,136-51,264$ & $63,399-65,934$ & $84,618-86,048$ \\
\hline
\end{tabular}

Table 6: Fine Motoric Ability Score Combination Group

Table 5 explains that there is an increase in fine motor skills in students who get the combination of playdough and coloring methods since the first week. The motor skills of most children become quite good. The average score increased higher than the other groups.

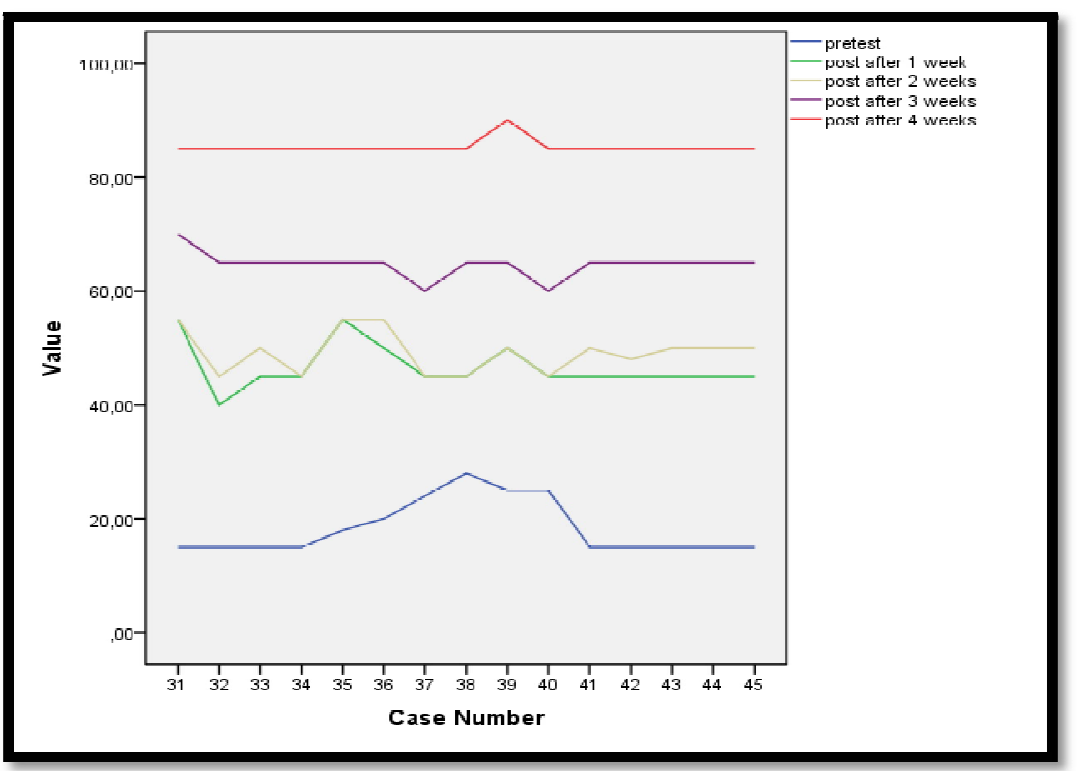

Figure 5: Line Diagram about the Fine Motoric Ability in the Combination of Colouring and Playdough Group 
Figure 4 explains that in the combination method there was an increase in fine motor skills of students became quite good that starting at second week until the end of $4^{\text {th }}$ week. All respondents had fine motor skills at a very good level. A very significant change from the beginning of the treatment until the end of the first week onwards shows that the combination of playdough and coloring drawing methods is very effective in accelerating the improvement of fine motor skills of pre-school children.

3.5. Effectiveness of Colouring, Playdough and Combination of two methods to Fine Motoric Ability at Pre School Student

\begin{tabular}{|c|c|c|c|c|c|c|}
\hline Source & $\begin{array}{c}\text { Dependent } \\
\text { Variable }\end{array}$ & $\begin{array}{l}\text { Type III } \\
\text { sum of } \\
\text { Square }\end{array}$ & df & $\begin{array}{l}\text { Mean } \\
\text { Square }\end{array}$ & $\mathbf{F}$ & $\begin{array}{c}P \\
\text { value }\end{array}$ \\
\hline \multirow{5}{*}{$\begin{array}{l}\text { Corrected } \\
\text { Model }\end{array}$} & Pre test & 0,267 & 3 & 0,089 & 0,004 & 1,000 \\
\hline & $\begin{array}{l}\text { Post 1st } \\
\text { week }\end{array}$ & 5864,583 & 3 & 1954,861 & 75,812 & 0,000 \\
\hline & $\begin{array}{l}\text { Post 2 nd } \\
\text { week }\end{array}$ & 2711,117 & 3 & 903,706 & 31,020 & 0,000 \\
\hline & $\begin{array}{l}\text { Post 3 rd } \\
\text { week }\end{array}$ & 1858,333 & 3 & 619,444 & 45,844 & 0,000 \\
\hline & $\begin{array}{l}\text { Post } 4 \text { th } \\
\text { week }\end{array}$ & 4483,333 & 3 & 1494,444 & 101,237 & 0,000 \\
\hline \multirow[t]{5}{*}{ Intercept } & Pre test & 20020,267 & 1 & 20020,267 & 847,120 & 0,000 \\
\hline & $\begin{array}{l}\text { Post 1st } \\
\text { week }\end{array}$ & 69700,417 & 1 & 69700,417 & 2703,063 & 0,000 \\
\hline & $\begin{array}{l}\text { Post 2 nd } \\
\text { week }\end{array}$ & 88550,417 & 1 & 88550,417 & 3039,488 & 0,000 \\
\hline & $\begin{array}{l}\text { Post 3 rd } \\
\text { week }\end{array}$ & 129735,000 & 1 & 129735,000 & 9601,533 & 0,000 \\
\hline & $\begin{array}{l}\text { Post } 4 \text { th } \\
\text { week }\end{array}$ & 269340,000 & 1 & 269340,000 & 18245,613 & 0,000 \\
\hline
\end{tabular}

Table 6: Test between Subjects at Serial Observation of Fine Motoric

Ability for All Group until $4^{\text {th }}$ Week

The results of multivariate ANOVA analysis explained that there were significant changes starting from the pretest to the end of the $4^{\text {th }}$ week after being given a coloring method and playdough to pre-school students. Improvements in fine motor skills were seen in the whole group.

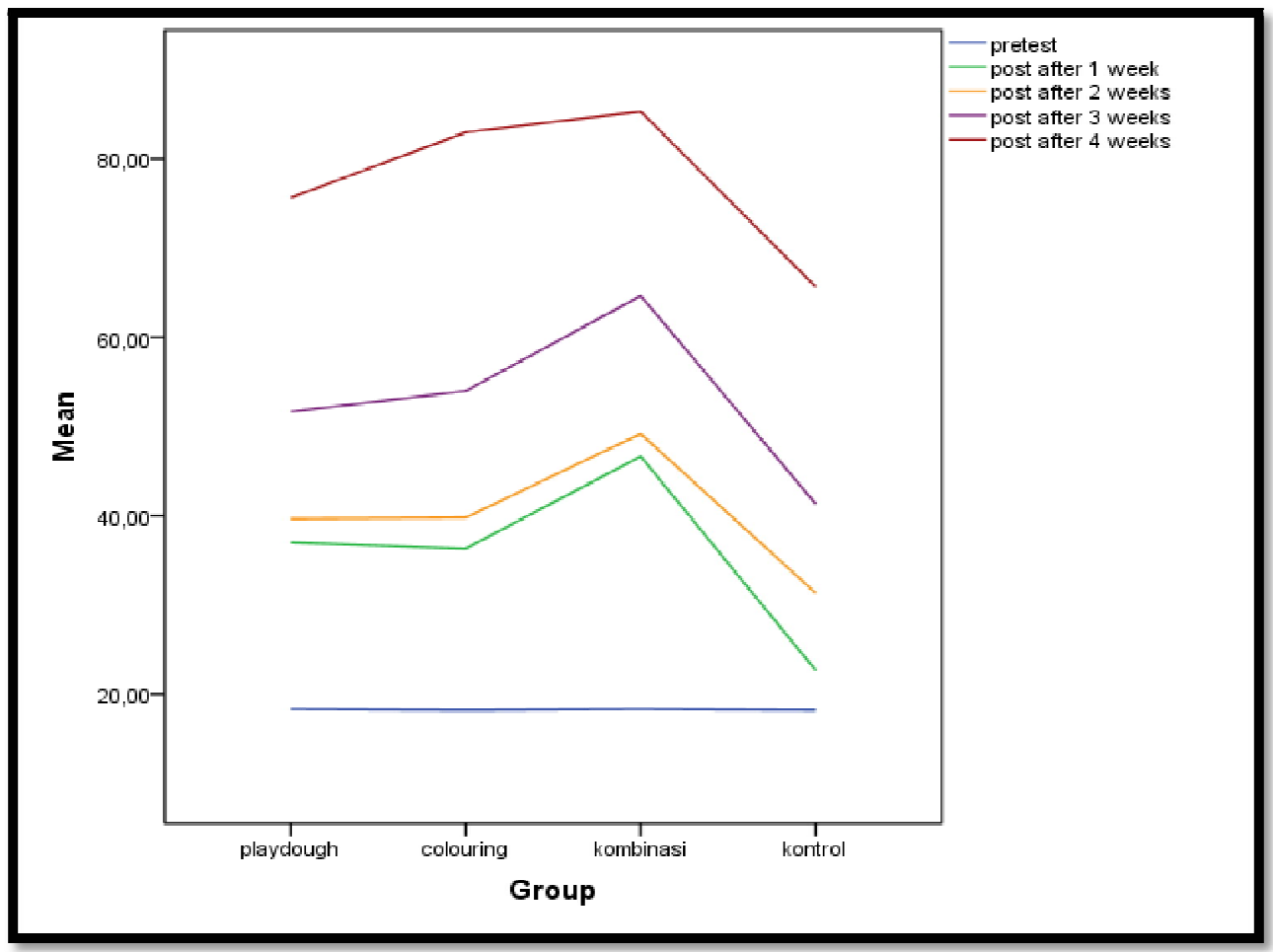

Figure 6: Line Diagram about the Comparison of Fine Motoric Ability in the Each Group 
The comparative test results presented in the form of figure 5 explain that the best method for improving fine motor skills of preschool-aged children is the combination of playdough and coloring pictures. Fine motor skills are organizing the use of small muscles such as fingers and hands that often require precision and coordination with the hands. Good fine motor skills to determine someone doing good activities too (Desta Sarasati Raharjo, 2014). Playdough game is one activity that is beneficial for the development of the child's brain. By playing playdough, children not only get pleasure, but also useful for improving brain development. With playdough, children can make any form with molds or with their own creativity (Haryani, 2014). The results of this study are in line with research (Desta Sarasati Raharjo, 2014) which states that respondents who think of fine motor development lack improvement in development fine motor skills become good. Drawing or coloring is a game that gives children the opportunity to be free of expression and very therapeutic (as a healing game). Children can express their feelings by drawing, this means drawing for children is a way to communicate without using words (Wowiling, 2014). This learning is supported by the use of crayons, which is one of the media that is easy for children to use to make streaks, has bright colors, has a larger diameter than a pencil, is very comfortable to hold (children's fingers are not easily tired), children are easier to make gradations of color, so as to provide opportunities for children to try, explore and discover their artistic abilities, as well as training the small muscles of the child, which are around the fingers of the child with a pleasant learning atmosphere. Given the many important effects of learning to color drawings for children, educators should start accustoming pupils to coloring pictures from an early age, which starts with images that are not too detailed so that children more easily apply the colors they want to scratch, not too many rules, both in the selection of colors and line boundaries so that children can explore by themselves. The combination and regular administration of learning methods using playdough and coloring are able to perfect the growth and development of pre-school age children.

\section{Conclusion}

The results of the study can be concluded that the playdough method has improved fine motor skills better than coloring, but a good combination of playdough and coloring in pre-school children for 1 month can improve fine motor skills of pre-school children very well. The combination method needs to be introduced and implemented by the teacher in an integrated manner with other stimulation fields in order to be able to perfect fine motor skills in pre-school children and ultimately be able to stimulate the creativity of pre-school age children.

\section{Acknowledgements}

We said thank you to the research and community directorate of the Republic of Indonesia's Ministry of Research and Technology for providing all facilities and funds to researchers so that they can carry out research that has a positive impact on the development of pre-school children in Indonesia. Besides that, gratitude is conveyed to the head of higher education service institution Seventh Region of east Java province who has provided motivation to all young lecturers in developing their science. Thank you to the chairman of Stikes Majapahit and the headmaster of the Dharma Wanita Gayaman, Al Akbar, Pembina Jabon and Tarbiyatush Shibyan Kindergarten who have supported the research well. Hopefully this research can improve the quality of early childhood education in Indonesia.

\section{References}

i. Alini. (2017). The Effect of Playdough Therapy on Preschool Children (3-6) Years Anxiety that is Hospitalized in Children's Care Rooms at RSUD Bankingan. Jurnal Ners Universitas Pahlawan Tuanku Tambusai. 2017 Oct 26;1(2).

ii. Desta Sarasati Raharjo, D. A., Dera Alfiyanti, S. Eko Purnomo (2014). The Effect of Scissors Play Therapy on the Improvement of Fine Motor in Children with Autism Ages 11-15 Years in the Extraordinary School of the State of Semarang. at http:/ / 182.253.197.100/ e-journal/index.php/ ilmukeperawatan/ article/ view/ 211

iii. Dewi Rohana, Z. N. (2017). Influence of Playdought Games Against Fine Motor Capabilities of Children 5-6 Years in Heaven Kid's Kindergarten, Handsome District of Pekanbaru City. E- Journal 29 April 2017. 1-12.

iv. Dhita Kris Prasetyanti, S. A. (2017). Effects of Playdough on Fine Motoric Development in Preschoolers. Jurnal Penelitian Keperawatan Vol. 3 (2) Agustus 2017, 124-130.

v. Dudley L \& Vasche T., 2010. Vision Therapy for a Patient with Developmental Delay, Journal of Behavioral Optometry. 21(2): 39-45. (10 September 2018). HYPERLINK "http:// www.oepf.org/jbo/journals/212\%20Dudley.pdf" www.oepf.org/jbo/journals/ 21-2\%20Dudley.pdf

vi. Fitriani. (2016). Effect of playdough media play therapy on fine motor skills in preschool children. Nursing Department of Medicine and Health Faculty. UIN Alauddin. Makasar. Thesis. Not published.

vii. Haryani, C. (2014). Application of Play Method with Playdought Media to Improve the Ability to Recognize the Concepts of Numbers and Symbols in Early Childhood. Teacher Training and Education Faculty. Thesis. not published.

viii. Jubaidah, Firda. (2018). The Effect of Giving Coloring Method on the Growth and Development of Preschool Children in Dharma Wanita 01 Kindergarten Pasirian District Lumajang Regency. Stikes Majapahit Mojokerto. Thesis. not published.

ix. Kusdyawati, A. (2009). The Effect of Coloring Play Therapy on the Acceptance of Oral Medicines in Pre-processing Children During Hospitalization in the Palm Room of Madiun District Hospital. Nursing Department of STIKES Satria Bhakti Nganjuk. Thesis. not published.

x. Lestari, Dwi Juli Ayu. (2018). The Effect of Playdough Therapy on the Development of Fine Motoric Children in SLB Sidoarjo Region. Nursing Bachelor Degree. Thesis. not published. 
xi. Nurhaeni, N., Annisa, F.,., \& Wanda, D. (2017). Application of Levine Conservation Theory in Child Nursing with Cases of Infection and Fluid. Keperawatan, 6(2)

xii. Nurhaeni. (2017). The Influence of the Use of Plasticine Media on the Improvement of Fine Motoric in Aisyiyah Kindergarten Student at Tabaringan Makassar City.Jurnal Andaragogi, Vol 11, Nomor 1. Juni 2017.

xiii. Paat, T. C. (2010). Analysis of the Effects of Play Therapy on Cooperative Behavior in Preschool Children (3-6 Years) During Treatment in the Esther Room of the Pancaran Kasih General Hospital, Manado. Manado: Universitas Sam Ratulangi. Thesis.

xiv. Ratnasari, Lusiana Dewi. (2017). Efforts to Improve the Cognitive Abilities of Autistic Children Through Music Learning Strategies in Autistic Special Schools Bina Anggita Gedong Kuning Yogyakarta Academic Year 2016-2017. Thesis. Early Childhood Islamic Education Study Program, Faculty of Tarbiyah and Teacher Training, Sunan Kalijaga State Islamic University. Yogyakarta.. Dalam http: HYPERLINK "https:/ / www.google.com/ url?sa=t\&rct=j\&q=\&esrc=s\&source=web\&cd=7\&ved=2ahUKEwi3j9XO5vLdAhUW3Y8 KHc2TBBkQFjAGegQIABAC\&url=http\%3A\%2F\%2Fdigilib.uin-suka.ac.id\%2F28821\%2F1\%2F13430037_BABI IV-atau-V DAFTAR-PUSTAKA.pdf\&usg=AOvVaw2gUwKDILTQwiwBY1MNXK4R" digilib.uin-suka.ac.id

xv. Sisiliani, Bernadeta Rsista. (2015). Improvement of the Fine Motor Ability of Children with Developmental Disabilities Category Medium Class Through Playdought / Dough in Damayanti Special School Yogyakarta. Yogyakarta: Universitas Negri Yogyakarta .

xvi. Wowiling, F.E., Ismanto, A.Y. and Babakal, A., (2014). Effect of Coloring Play Therapy on the Level of Anxiety in School-age PRA Children Due to Hospitalization in the Irina E BLU RSUP. Prof. Dr. RD Kandou Manado. JURNAL KEPERAWATAN, 2(2).

xvii. Yurika, Dewi. 2009. Effectiveness of health education on mothers' knowledge, attitudes and skills in monitoring the development of children under five in Sukaramai Village, Baiturrahman District, Banda Aceh. PhD Thesis. Universitas Indonesia. Fakultas Ilmu Keperawatan. 